\title{
Antidiabetic and Antiatherosclerotic activity of dried red radish roots (Raphanus sativus $L$ ) on hypercholesterolemic diabetic rats
}

\author{
Abeer A. Khedr - Naglaa A. El Sheikh \\ Dep. of Nutrition \& Food Science, Faculty of Home Economics, Menoufia \\ University, Khedr_a@yahoo.com
}

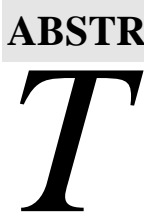

good quantities of bioactive compounds as phenolic compounds, flavonoids and anthocyanin also its antioxidant activity. Rats were randomly divided into two main groups, the first group is normal control, and the second is the hypercholesterolemic diabetic rats which were divided into four subgroups (8 rats each) as follow: subgroup 1 served as positive control group, subgroup 2, 3 and 4 were fed on the diet containing $2.5 \%$, 5\% and $7.5 \%$ of dried red radish roots powder for 6 weeks respectively. After completing the treatment period, blood samples were collected for used to the biochemical analysis as blood glucose, insulin and lipid profile. Heart were taken for aortic histopathological. The results indicated that treatments with dried red radish roots significantly decreased the levels of blood and urine glucose, lipid profile, hepatic lipid and atherogenic indices compared to positive control group and improved the level of insulin and histopathological changes in the aorta of hypercholesterolemic diabetic rats. In conclusion, red radish roots as a source of antioxidant compounds had hypoglycemic effect, improved lipid metabolism and prevent cardiovascular diseases.

Keywords: red radish roots - atherogenic indices - antidiabetic activity - hypercholesterolemic diabetes rats. 


\section{INTRODUCTION}

\section{Diabetes}

and

cardiovascular disease are the major causes of morbidity and mortality. Epidemiological studies suggested that the risk factors for cardiovascular disease and diabetes include hypercholesterolemia and hyperglycemia, which are largely influenced by diet (Kaur et al., 2002 and Tourlouki et al., 2009). Diabetes mellitus (DM), a heterogeneous metabolic disorder, is an increasing worldwide health problem and manifests hyperglycemia and other symptoms (Kawamori, 2002). DM is associated with premature and accelerated atherosclerosis (Tomkin, 2010). The overall risk of cardiovascular disease (CVD) for people with DM increases two- to three fold in men, and three to five fold in women when compared to people without DM (Standl $\boldsymbol{e t}$ al., 2009). Depending on the assessment methodology, approximately $50-70 \%$ of all people with DM (both type 1 and type 2), die due to CVD (Standl et al., 2009). Diabetic complications correlate with hyperglycemic levels and also with length of exposure to hyperglycemia. Both type 1 and type 2 of diabetes mellitus are associated with accelerated atherosclerosis. Strong epidemiological evidence supports an association between glycemic control and CVD risk (Prince et al., 2007).

Laboratory and clinical studies have shown that a diet supplemented with fruit and vegetables had beneficial effects on diabetes and atherosclerosis (Adams et al., 2006; Bazzano et al., 2008 and Mirmiran et al., 2009). Radish is commonly cultivated in the world for its edible roots. The most common radish cultivars are the wellknown red varieties, while other varieties vary in size, color (Gutierrez and Perez 2004; Hara et al., 2009). Its fresh roots can be cooked or processed by pickling or drying. Radish contains very potent phytochemicals, glucosinolates, (Mithen et al., 2010). And high content of flavonoids, including anthocyanins (Lin et al.,(2011) and Tamura et al. 2010). Also radishes are rich in ascorbic 
Antidiabetic and Antiatherosclerotic activity of dried red radish roots (Raphanus sativus $L$ ) on hypercholesterolemic diabetic rats

Abeer A. Khedr-Naglaa A. El Sheikh

acid, folic acid, vitamin B6, riboflavin, potassium, magnesium, copper, and calcium (Jan and Badar, 2012). The radish has been used in some societies as a laxative, stimulant, digestive acid, appetizer, and to treat stomach disorders (Gilani and Ghayur 2004). Also Curtis, (2003) suggested that radish can be used as an alternative treatment for various ailments including hyperlipidemia, coronary heart diseases, cancer. Therefore the present study investigated the influence of dried red radish roots to improve diabetic parameters, lipid profile and atherogenic indices in hypercholesterolemic diabetic rats.

\section{MATERIALS \& METHODS}

\section{Materials:}

Fresh red radish roots: Fresh red radish roots (R. Sativus) vegetables were purchased from a local market (Shiben El-Kom, El- Menoufia, Egypt).

Chemicals: Alloxan monohydrate (Sigma-Aldrich Company, St. Louis, Missouri,
USA), Pure cholesterol was obtained from Winlab (UK), cholic acid was obtained from Biomark (India) and methyl thiouracil was purchased from Sigma-Aldrich (USA).

Kits of glucose, total cholesterol (T.C), triglyceride (T.G), were purchase from SPINREACT, S.A.U. Ctra. santa Coloma,7E17176 SANT ESTEVE DE BAS (GI) Spain. Insulin ELISA kits from KAMIYA biochemical company 12779 Gateway Drive, Seattle, WA 98168, USA.

Animals: Forty eight adult male Sprague-Dawley rats weighing (245-250 g), at the beginning of the experiment, were obtained from Medical Insects Research Institute, Doki, Cairo, Egypt.

Standard diet was prepared from fine ingredients according to AIN-93 guidelines (Reeves et al., 1993).

\section{Methods:}

Preparation of red radish roots powder

The roots were washed to remove soil and dust, and were then rinsed carefully with distilled water and cut to regular 
Abeer A. Khedr-Naglaa A. El Sheikh

slides. After that, radish roots were dried in Alab Tech oven under vacuum (Model No. Lvo2040- Korea) at $50^{\circ} \mathrm{C}$. It were ground in an electric mill and passed through 80 mesh sieves (British standard screen). The fine powder was kept in glass containers and stored at $-20{ }^{\circ} \mathrm{C}$ until used.

The chemical composition of dried red radish roots (moisture, crude protein, fat, crude fiber, and ash) were determined as described in the AOAC procedures (2012). Total carbohydrate was estimated by phenol sulfuric according to Sadasivam and Manickam (1997). Total calories were calculated on the basis of a $100 \mathrm{~g}$ sample using 9, 4 and $4 \mathrm{Kcal}$ for fat, protein and carbohydrate, respectively.

Antioxidant activity of dried red radish roots extract was determined by 2, 2 diphenyl-1-picrylhydrazyl (DPPH) according to Yang et al., (2006). Total phenolic compounds were expressed as mg gallic acid equivalents / 100 $\mathrm{g}$ dry weight sample. Total flavonoids were determined using a method described by Franke et al., (2004).
Anthocyanin was determined as described by Lako et al., (2007).

\section{Experimental design:}

Rats were housed individually in wire cages under the normal laboratory conditions in Biological Laboratory, Faculty of Home Economics, Menoufia University. Rats were fed on standard diet for one week as an adaptation period. Diet was introduced to rats in special food cups to avoid scattering of food. Also, water was provided to rats by glass tubes projecting through the wire cages from an inverted bottle supported to one side of the cage. Food and fresh water were provided checked daily. Rats were randomly divided into two main groups, the first group, normal control group $(n=8)$ fed standard diet. The rats $(n=40)$ were fasted overnight prior to injection of alloxan dissolved in normal saline at a dose of 150 $\mathrm{mg} / \mathrm{kg}$ body weight given intraperitoneally (Aruna et al., 1999). Diabetes was identified by visual observations and measuring blood glucose concentration $72 \mathrm{~h}$ after injection of alloxan. Rats with a fasting 
blood glucose level above 200 $\mathrm{mg} / \mathrm{dl}$ were considered diabetic and were used in this study Then, all diabetic rats were fed on diet containing with diet composed of cholesterol (1\%), cholic acid (0.2\%), lard (4\%), egg yolk (7\%), methyl thiouracil $(0.2 \%)$, sodium chloride $(1 \%)$, wheat bran $(6.6 \%)$, wheat flour (45\%) and corn starch (35\%) for six weeks according to the method described by Pengzhan et al., (2003) to induced Hypercholesterolemia. Total cholesterol (TC) and low density lipoprotein (LDL.c) were determined to assessment of hypercholesterolemia. After divided into four subgroups (8 rats each) as follow: subgroup 1 served as positive control group, subgroup 2, 3 and 4 were fed on the diet containing $2.5 \%, 5 \%$ and $7.5 \%$ of dried red radish roots powder for 6 weeks respectively, this dose was guided by previous study Taniguchi et al., 2006. After completing the treatment period, animals were sacrificed under diethyl ether anesthesia. Blood samples were collected from the hepatic portal vein, for used to the biochemical assays. Heart were taken and washed in saline solution until all blood was removed for Aortic histopathological.

\section{Biochemical assays:}

The serum levels triglyceride (TG), total cholesterol (TC). High-density lipoprotein cholesterol (HDL-c), were measured with an automatic analyzer using a diagnostic kit for each according to Fossati and Prencipe (1982); Allain et al., (1974) and Burstein et al., (1980) respectively. Glucose was measured in blood and urine according to Hugget and Nixon (1957). The concentration of serum insulin was determined with a Rat insulin ELISA kit Insulin sensitivity from the final fasting insulin and glucose values was estimated by the Homeostasis model assessment of insulin resistance (HOMAIR) according to the following formula: [fasting glucose $(\mathrm{mM})$ $\times$ fasting insulin $(\mathrm{mUI} / \mathrm{L})] / 22.5$ (Cordero-Herrera et al., 2015). Low Density Lipoprotein (LDL.c) was calculated from friedewald formula $\mathrm{LDL}, \mathrm{c}=\mathrm{TC}$ - HDL.c - TG/5.0 (mg/dL) 
(Friedewald et al., 1972). The Atherogenic ratios were calculated as follows: Atherogenic Index of Plasma $(\mathrm{AIP})=\log \mathrm{TG} / \mathrm{HDLc}$, Cardiac risk ratio $(\mathrm{CRR}),=\mathrm{TC} / \mathrm{HDLc}$ Castelli's Risk Index (CRI) = LDLc/HDLc, Atherogenic Coefficient $(\mathrm{AC})=(\mathrm{TC}-\mathrm{HDLc})$ / HDLc according to Bhardwaj et al., (2013) and Atherogenic fraction (AF) was calculated as the difference between $\mathrm{TC}$ and HDL-C according to Aguilar $\boldsymbol{e t}$ al., (2011).

\section{Analyses of hepatic lipid profile}

The content of hepatic total lipids, triglyceride and total cholesterol were analyzed as described previously Bligh and Dyer (1959) ; Hossain et al., (2011) and Shahdat et al.,(2004) respectively.

Histopathological Staining of Aorta

Aortic tissues were fixed in $10 \% \quad(\mathrm{v} / \mathrm{v})$ formalin in $0.01 \mathrm{Mphosphate}$ buffered saline (PBS) for 2 days with change of formalin solution every day to remove traces of blood from tissue. The tissue samples were dehydrated and embedded in paraffin, and then thin sections (6m) of the aortic arch in each group were cut and stained with hematoxylin eosin according to kho et al., (2014).

\section{Statistical analysis:}

Results were expressed as the mean \pm SD. Data for multiple variable comparisons were analyzed by one-way analysis of variance (ANOVA). For the comparison of significance between groups, Duncan's test was used as a post hoc test according to the statistical package program (Armitage and Berry, 1987).

\section{RESULTS \& DISCUSSION}

Data in Table (1) showed total phenolic compounds, total flavonoids, anthocyanin, antioxidant activity and proximate chemical composition of dried red radish roots. Total phenolic, total flavonoids, anthocyanin and antioxidant activity of dried red radish roots were $11.68 \mathrm{mg}$ gallic/100 $\mathrm{g}$, $18.52 \mathrm{mg}$ catechin/100 g, 29.69 mg cyaniding -3- glucoside/100 $\mathrm{g}$ and $82.15 \%$ respectively. Goyeneche et al., (2015) 
reported that total phenolic, total flavonoids and antioxidant activity of red radish roots were $341.45 \mathrm{mg}$ gallic acid equivalent (GAE) /100 g dry matter (d.m.), $267.47 \mathrm{mg}$ quercetin /100 g d.m. and $1.36 \mathrm{mmol}$ trolox equivalent (TE) $/ 100 \mathrm{~g}$ d.m. respectively. The red radish is characterized by a high flavonoid content including quercetin and kaempferol, high levels of anthocyanin and phenolic compounds reported by Hanlon and Barnes (2011). A radish roots extract had in vitro antioxidant activity (Lugsai $\boldsymbol{e t}$ al., 2005).

Also, in Table (1) the dried red radish roots had 16.49 $\mathrm{g} / 100 \mathrm{~g}$ moisture, $0.62 \mathrm{~g} / 100 \mathrm{~g}$ total fat, $6.67 \mathrm{~g} / 100 \mathrm{~g}$ crude protein, $48.56 \mathrm{~g} \quad / 100 \mathrm{~g}$ carbohydrate, $21.06 \mathrm{~g} / 100 \mathrm{~g}$ fiber and $6.60 \mathrm{~g} / 100 \mathrm{~g}$ total ash. Energy content was $226.5 \mathrm{Kcal}$. Goyeneche et al., (2015) found that dried red radish roots contain moisture (16 g/100g), crude protein $(10.06 \mathrm{~g} / 100 \mathrm{~g})$, lipid content $(1.24 \mathrm{~g} / 100 \mathrm{~g})$, ash $(13.59 \mathrm{~g} / 100 \mathrm{~g})$, crude fiber $(5.65$ $\mathrm{g} / 100 \mathrm{~g}$ ) and carbohydrates (53.47 g /100g). Levine et al., (2008) reported that high concentration of complex carbohydrates and dietary fiber in radish roots is one of the nutritional benefits.

Effect of dried red radish roots on glucose in blood and urine and insulin in normal and hypercholesterolemic diabetic rats are represented in Table (2). The data indicated that hypercholesterolemic diabetic rats had significantly $(\mathrm{P} \leq 0.05)$ high blood glucose level as compared with normal rats. At the final day of the experimental period, blood glucose level still high in the untreated hypercholesterolemic diabetic rats but in hypercholesterolemic diabetic rats treated with $2.5,5$ and $7.5 \%$ of dried red radish roots blood glucose level were decreased by $24.2,37.29$ and $50.15 \%$ respectively compared to the initial day. The highest reduction in blood glucose level was noted in hypercholesterolemic diabetic rats treated with $7.5 \%$ of dried red radish roots. These results were in agree with Aly et al., (2015) who showed that Egyptian radish had a hypoglycemic effect in diabetic 
status. Raphanus satives roots juice possesses good hypoglycemic potential coupled with antidiabetic efficacy (Shukla et al., 2011). The hypoglycemic effect of red radish roots may be due to its content of flavonoids and anthocyanins. Vinayagam and Xu (2015) suggest that anthocyanins had antidiabetic activities Also, the consumption of flavonoids or flavonoids - rich foods may reduce the risk of diabetes reported by Bahdoran et al., (2013). On the other hand, glucose was not detected in the urine of normal rats, while hypercholesterolemic diabetic untreated rats $(0 \%$ red radish roots) were highly glycosuric. At the final day of the experiment, the treatment with $2.5,5$ and $7.5 \%$ of dried red radish roots resulted in a significant $(\mathrm{P} \leq 0.05)$ reduce in urine glucose level by $29.31, \quad 50.46$ and $69.95 \%$ respectively in comparison with the initial day. Moreover, dried red radish roots at concentration $7.5 \%$ was identified as the most effective in lowering urine glucose level. Shin et al., (2015) suggested that radish contains a variety of antioxidant constituents, which may play important roles in body homeostasis in vivo.

The results in the same table illustrated that there were significant decrease $(\mathrm{P} \leq 0.05)$ in serum insulin level in hypercholesterolemic diabetic rats as compared to normal rats. On the other hand, a significant increase $(p \leq 0.05)$ in serum insulin level was observed in hypercholesterolemic diabetic rats treated with $2.5,5$ and $7.5 \%$ of dried red radish roots in the final day of experiment period, whereas serum insulin level was increased by $47.06,117.78$ and $138.46 \%$ respectively for the first day of experiment. Furthermore

hypercholesterolemic diabetic rats treated with 5 and $7.5 \%$ dried red radish roots had the highest insulin sensitivity index value than rats treated with $2.5 \%$ $(\mathrm{P} \leq 0.05)$. These obtained results were in accordance with results of Aly et al., (2015) and Amer et al., (2004) who reported that antioxidants, such as flavonoids and phenols in Egyptian and Japanese radish improved insulin sensitivity and thereby 
induced the hypoglycemic effect.

Table (3) shows the effect of dried red radish roots on serum lipid profile in normal and hypercholesterolemic diabetic rats. The results indicated that the levels of serum total cholesterol (T.C), triglyceride (T.G), LDL-c and VLDL-c were significantly increased $\quad(\mathrm{P} \leq 0.05) \quad$ in hypercholesterolemic diabetic rats as compared to those of the normal control rats, while HDLc had an opposite trend. These result agree with those obtained by Aly et al. (2015) and Haque et al., (2014) who found that the levels of serum and plasma lipid profile (TC, TG, LDL-c and VLDl-c) increased in hypercholesterolemic diabetic rats. Any changes in the levels of lipids make the individuals more inclined to develop atherosclerotic cardiovascular diseases as well as endothelial dysfunction (Parinita, 2012). The abnormal high concentration of serum lipids in diabetic rats are due mainly to an increase in the mobilization of free fatty acids from the peripheral fat depots, since insulin inhibits the hormone sensitive lipase departed by Pushparaj et al., (2000). The levels of TC, TG, LDL-c and VLDL-c in serum significantly $(\mathrm{P} \leq 0.05) \quad$ decreased in hypercholesterolemic diabetic rats treated with different concentrations of red radish roots compared with untreated rats ( $0 \%$ red radish roots group), while no significant $(\mathrm{P}>0.05)$ differences were observed in TC and LDL-c between hypercholesterolemic diabetic rats treated with $2.5 \%$ and $5 \%$ of red radish roots (Table 3). Also, the treatment of $7.5 \%$ red radish roots was more effective $(p \leq 0.05)$ in reducing the levels of TC, TG, LDL-c and VLDl.-c and increasing HDL-c compared to other concentrations. These effects may be due to Raphanus sativus increases the lipid metabolism and lowers the lipid plasma by increasing the activity of lipoprotein lipase reported by Yoshida et al., (2005). These results agree with those obtained by Haque et al., (2014) who found that the levels of plasma T.C, T.G and LDL-c significantly reduced in 
hypercholesterolemic rats treated with hot water radish extract. Also, fresh red radish roots juice decreased serum T.C, T.G, LDL$c$ and VLDL-c and elevated the level of HDL- $\mathrm{c}$ in rats reported by Sadeek (2011). The improvement of serum lipid profile in rats treated with different concentrations of dried red radish roots may be related to its content of flavonoid, whereas higher dietary flavonoid intake was associated with improving lipid profile (Li et al., 2013). However, Taniguchi et al., (2006) reported that no significant changes were observed in the lipid profiles in diabetic rats fed $0 \%, 2.5 \%$ and $5 \%$ of Japanese radish (JRS), although JRS decrease T.G. Because a risky relationship between serum lipids and cardiovascular disease has been reported by He et al., (2004), lowering serum cholesterol and triglyceride levels is important for the prevention of high mortality lifestyle - related cardiovascular disease.

The results of Table (4) show effect of dried red radish roots on atherogenic indices and
LDL-c/HDL.-c Ratio (HTR\%) in normal and hypercholesterolemic diabetic rats. A significant increase $(\mathrm{P} \leq 0.05)$ in Atherogenic Index (AI), cardiac risk ratio (CRR\%), castelli's Risk Index (CRI), Atherogenic fraction (AF) and Atherogenic coefficient (AC) were observed in hypercholesterolemic diabetic rats compared to normal rats. However, HTR\% of hypercholesterolemic diabetic rats were lower $(\mathrm{P} \leq 0.05)$ than normal rats. These results could be attributed high serum levels of TC, TG, LDL-c and VLDL.-c as well as lower levels of HDL.c which was observed in hypercholesterolemic diabetic rats. The present results were in accordance with those of Adaramoye and Akanni (2014) who showed that hypercholesterolemic rats had high serum, hepatic and cardiac TC,TG and LDL-c. Diabetes is associated with abnormalities of lipid metabolism and an increase in the atherogenic index (Tripathi, 2003). Atherogenic indices are powerful indicators of the risk of cardiovascular diseases, the higher the 
atherogenic indices value, the higher the risk for developing cardiovascular diseases reported by chigozie and chidinma (2013). On the other hand, Atherogenic index (AI) was significantly reduced $(\mathrm{P} \leq 0.05)$ in hypercholesterolemic diabetic rats treated with $2.5,5$ and $7.5 \%$ of dried red radish roots compared with hypercholesterolemia diabetic rats untreated $(0 \%$ red radish roots), while $\mathrm{HTR} \%$ had an opposite trend. However, treatments with 5 and $7.5 \%$ of dried red radish roots had significantly decreased $(\mathrm{P} \leq 0.05)$ in $\mathrm{CRR} \%, \mathrm{CRI}, \mathrm{AF}$ and $\mathrm{AC}$ in hypercholesterolemic diabetic rats in comparison to hypercholesterolemic diabetic rats untreated $(0 \%$ red radish roots). Moreover, the highest reduction $(\mathrm{P} \leq 0.05)$ in $\mathrm{AI}$, $\mathrm{CRR} \%, \mathrm{CRI}, \mathrm{AF}$ and $\mathrm{AC}$ and the highest elevation $(\mathrm{P} \leq 0.05)$ in HTR\% were observed in hypercholesterolemic diabetic rats treated with $7.5 \%$ of dried red radish roots compared to other concentrations. These finding agree with those reported by Haque et al., (2014) who found that the atherogenic index reduced by $24 \%$ in the hypercholesterolemic rats treated with Raphanus sativus extract, as noted the atherogenic indices were reduced significantly in the hypercholesterolemic rats as a result of oral administration of Raphanus sativus extract. Low atherogenic indices are protective against coronary heart disease (Chigozie and Chidinma, 2013). Thus radish roots had good protective effects against cardiovascular complications.

Data recorded in Table (5) showed effect of dried red radish roots on hepatic lipid parameters in normal and hypercholesterolemic diabetic rats. The results revealed that hypercholesterolemic diabetic rats had significantly $(\mathrm{P} \leq 0.05)$ high total lipids (T.L), triglyceride (T.G) and total cholesterol (T.C) levels comparing to normal rats. This was in agreement with the results of Haque et al., (2014) and Mariee et al., (2012) who reported that hypercholesterolemic rats showed a marked elevated in the levels of hepatic T.C and T.G. 
Elevated liver TG was caused by increasing the rate of hepatic lipogenesis, concomitantly with the ability of ROS to block its secretion into the plasma (Ferreira Ede et al., 2011). Furthermore, Halim et al., (1997) indicated that high contents of liver cholesterol are due to disturbed catabolism of cholesterol into bile acids. In contrast of these results Taniguchi et al., (2006) observed that hepatic T.G level reduced in diabetic rats.

From Table (5) it was obvious that there was a significant decrease $(P \leq 0.05)$ in hepatic T.L and T.G in hypercholesterolemic diabetic rats treated with $2.5 \%, 5 \%$ and $7.5 \%$ of red radish roots as compared to untreated rats $(0 \%$ red radish roots), however hepatic T.C was significantly $(\mathrm{p} \leq 0.05) \quad$ decreased in hypercholesterolemic diabetic rats treated with 5 and $7.5 \%$ of dried red radish roots compared with untreated rots. The highest significant reduction in hepatic T.L, T.G and T.C levels was observed in hypercholesterolemic diabetic rats treated with $7.5 \%$ of red radish roots. The hot water radish extract reduced the hepatic T.C and T.G levels in hypercholesterolemic rats, the hypercholesterolemic of radish might be related to the ingestion of saponin - rich foods such as Radish might had increased fecal excretion of cholesterol led to decreased hepatic cholesterol (Haque et al., 2014 and Zhao et al., 2008). The obtained results were in accordance with results of Castro - Torres et al., (2014) who found that black radish juice reduces hepatic cholesterol level. Also, Rahman et al., (2013) reported that the extract of Raphans sativus Linn (Radish) significantly decreases the serum and liver cholesterol.

Figure (1) showed the histopathological changes of aorta tissue in normal and hypercholesterolemic diabetic rats. From the histopathological examination of the rat aorta section under study, the section of the aorta of normal rats showed no histopathological changes (normal tunica media) (H \& $\mathrm{E} X$ 400) (fig.1A). Hypercholesterolemic diabetic 
rats untreated $(0 \%$ red radish roots) showed vacuolation of the smooth muscles of tunica media of aorta (H \& E X 400) (fig.1B). Smooth muscle degeneration together with cell proliferation in aorta was observed in diabetic rats (Karasu et al., 1997). Hypercholesterolemic rats had aorta with disorder arrangement unclear borderlines and partial deletion as well as increased foam cell formation and tunica media thickness of the vascular walls reported by Deng et al., (2015).

However, hypercholesterolemic diabetic rats treated with $2.5,5$ and $7.5 \%$ of dried red radish roots, their aorta sections appeared normal (H \& E X 400) (fig.1C, D and E respectively). Haque et al., (2014) who found that Raphanus sativus extract possess protective effects against cardiovascular complications. Crude radish extract (Raphanus sativus, Korean white radish) inhibits cell proliferation in mouse aortic smooth muscle cells (Suh et al., 2006), suggesting that radish isothiocyanates may protect against abnormal cell proliferation in vascular smooth muscle cells.
In conclusion, all of the results indicate a possible protective mechanism of the dried red radish roots against the development of atherosclerosis and coronary heart disease as well as the dyslipidemic conditions that characterize diabetes mellitus. Results showed that dried red radish roots which are a rich source of flavonoids and anthocyanins have hypoglycemic effects and can improve the levels of insulin and lipid metabolism in rats. Therefore, red radish roots in everyday diet would be beneficial.

\section{REFERENCES}
A.O.A.C. (2012):
International
Official
Methods of Analysis. 19 ed., Gaithersburg, MD: AOAC International.

\section{Adams MR; Golden DL; Chen $\mathrm{H}$; Register TC and Gugger ET(2006):}

A diet rich in green and yellow vegetables inhibits atherosclerosis in mice. $\mathrm{J}$. Nutr., 136:1886-9. 
Adaramoye OA and Akanni O O (2014):

Effects of methanol extract of breadfruit (Atrocarpus altilis) of atherogenic indices and redox status of cellular system of hypercholesterolemic male rats. Advan. Pharm. Sci., $1-11$.

Aguilar EC; Queiroz MG; MU $\mathrm{N}$ and Oliveira DA (2011):

Serum lipid profile and hepatic evaluation in mice fed diet containing pequinut or pulp (Caryocar brasiliense Camb.) . Ciênc. Tecnol.

Aliment, Campinas, 31(4): 879883.

\section{Allain CC; Poon LS; Chan} CSG; Richmond $W$ and Fu PC (1974):

Enzymatic determination of total serum cholesterol. Clin. Chem., 20(4): 470475.

\section{Aly TA; Fayed SA; Ahmed AM and EL Rahim EA (2015):}

Effects of Egyptian radish and clover sprouts on blood sugar and lipid metabolisms in diabetic rats. J. Biotech. and Biochem., 10(1): 16-21.

Amer M; EL- Habibi ES and EL-Gendy A (2004): Effects of trifolium alexandrinum extracts on streptozotocin- induced diabetes in male rats. Ann. Nutr. Metab., 48: 343-347.

\section{Artimage GY and Berry WG (1987): \\ Statistical Methods 7th Ed. Ames, Iowa State University Press, 39-63.}

\section{Aruna RV; Ramesh B and kartha VNR (1999):}

Effects of betacarotene on protein glycosylation in alloxan induced diabetic rats. Indian Journal of Experimental Biology. $.37(4$,$) ): 399-401.$

\section{Bahadoran Z; Mirmiran P} and Azizi F (2013):

Dietary polyphenols as potential nutraceuticals in management of diabetes: 
A review. J. Diabetes

Metab. Disord.,12-43. precipitation

with

polyanions.Scand J. Clin.

Lab. Invest., 40: 583-595.

Bazzano LA; Li T Y;

Joshipura $\mathrm{K} J$ and Hu

FB (2008):

Intake of fruit, vegetables, and fruit juices and risk of diabetes in women.

Diabetes Care. 31: 1311-7.

Bhardwaj S; Bhattacharjee J;

Bhatnagar MKT and Vagi S (2013):

Atherogenic index of plasma, castelli risk index and atherogenic coefficient- new parameters in assessing cardiovascular risk. IJPBS. 3(3): 359-364.

Bligh EG and Dyer WJ (1959):

A rapid method of total lipid extraction and purification. Canadiam Journal of Biochemistry and Physiology, 378:. 911-917.

\section{Burstein M; Scholnick H R} and Morfin R (1980):

Rapid method for the isolation of lipoproteins from human serum by
Castro-Torres IG; De la OAM; Gallegos-Estudillo J; Naranjo-Rodriguez EB and Dominguez Ortiz MA (2014):

RaphanussativusL.varnige rasa source of phytochemicals for the prevention of cholesterol gallstones. Phytother Res 28:167-171.

Chigozie I.J and Chidinma I C (2013):

Positive moderation of the hematology, plasma biochemistry and ocular indices of oxidative stress in alloxan-induced diabetic rats, by an aqueous extract of the leaves of Sansevieria liberica Gerome and Labroy. Asian Pac. J .Trop. Med., 6: 27-36

Cordero-Herrera MMÁ; Goya $L$ and Ramos S (2015):

Cocoa intake ameliorates hepatic oxidative stress in 
young Zucker diabetic fatty rats. Food Research International 69: 194-201.

\section{Curtis IS (2003):}

The noble radish: past, present and future. Trends in Plant Science, 8: 305307.

Deng ZY; Hu MM; Xin YF and Gang C (2015):

Resveratrol alleviates vascular inflammatory injury by inhibiting inflammasone activation in rats with hypercholesterolemia and vitamin D2 treatment. Inflamm. Res., 64:321332.

Ferreira ES; Silva MA; Demonte $A$ and Neves VA (2011):

Soy $\beta$-conglycinin (7S globulin) reduces plasma and liver cholesterol in rats fed hypercholesterolemic diet. J. Med. Food. 14: 94-100.

Fossati $P$ and Prencipe $L$ (1982):
Serum triglycerides

determined calorimetrically with an enzyme that produces hydrogen peroxide. Clin. Chem., 28(10): 2077-80.

Franke AA; Custer LJ; Arakaki $C$ and Murphy S P (2004):

Vitamin $\mathrm{C}$ and flavonoid levels of fruits and vegetables consumed in Hawaii, Journal of Food Composition and Analysis, 17(1): 1-35.

Friedewald WT; Levy $R$ and Fredrickson D S (1972):

Estimation of the concentration of low density lipoprotein cholesterol in plasma without use of the preparative ultracentrifuge. Clin. Chem., 18: 499-502.

Gilani AH and Ghayur MN (2004):

Pharmacological basis for the gut stimulatory activity of Raphanus sativus leaves. J Ethnopharmacol 95: 169-172. 
Goyeneche R; Roura S; Ponce A; Vega-Galvez A; Ouispe-fuentes I and Uribe E (2015) :

Chemical characterization and antioxidant capacity of red radish (Raphanus sativus L.) leaves and roots. Journal of Functional Foods. 16: 256264.

Gutierrez RM and Perez R L(2004):

Raphanus sativus (Radish): their chemistry and biology. Scientific World Journal 4:811-837

Halim A B; El-Ahmady O; Hassab-Allah S; AbdelGalil, F; Hafez $Y$ and Darwish A(1997):

Biochemical effect of antioxidants on lipids and liver function in experimentally-induced liver damage. Ann. Clin. Biochem.,34(6):656-663.

Hanlon PR and Barnes D M (2011):

Phytochemical composition and biological activity of 8 varieties of radish (Raphanus sativus L.) sprouts and mature taproots. J. Food Sci., 76:C185-C192

Haque M; Islam J; Rahaman A; Selina FA; Rahman MA; Hasan $M$ and Hossain S (2014):

Raphanus sativus ameliorates atherogenic lipid profiles in hypercholesterolemic rats and hypercholesterolemiaassociated peroxidative liver damage. $\mathrm{J}$ of Advances in Chemistry. 23: 1385-1394.

Hara M; Ito F; Asai $T$ and Kuboi T (2009):

Variation in amylase activities in radish (Raphanus sativus) cultivars. Plant Foods Hum Nutr 64: 188-192.

\section{He Y; Lam T H; Li LS; He S} F and Liang BQ (2004):

Triglyceride and coronary heart disease mortality in a 24-year follow-up study in Xi' an. China. Ann.

Epidemiol.,14: 1-7 
Hossain S; Chowdhury I.H; Basunia MA; Nahar T; Rahaman A and Choudhury B K et al., (2011):

Syzygium cumini Seed Extract Protects the Liver against Lipid Peroxidation with Concurrent Amelioration of Hepatic Enzymes and Lipid Profile of Alcoholic Rats. J Compl Integr Med., 8: 117.

Hugget ASG and Nixon DA (1957):

Use of glucose. Oxidase, peroxidase and Odianisidine in the determination of blood glucose and urinary glucose. Lancet, 273: 366370.

\section{Jan $M$ and Badar A (2012):}

Effect of crude extract of Raphanus sativus roots on isolated trachea of albino rat. Pak. J. Physiol., 8: 2326.

Karasu C; Ozansoy G; Bozkurt O; Erdogan D and Omeroglu S (1997):
Antioxidant

and

Triglyceridelowering effects of vitamin $\mathrm{E}$ associated with the prevention of abnormalities in the reactivity and morphology of aorta from streptozotocin- diabetic rats. Metabolism, 46(8): 872-879.

Kaur J; Singh P and Sowers J $R$ (2002):

Diabetes and cardiovascular diseases. Am. J .Ther ., 9:510-5.

Kawamori R (2002):

Diabetes trends in Japan.

Diabetes Metab. Res. Rev., 18: S9-S13

Kho M C; Lee YJ; Cha JD; Kang DG and Lee $H$ (2014):

Gastrodia elata

Ameliorates High-

Fructose Diet-Induced Lipid Metabolism and Endothelial Dysfunction. Evidence-Based Complementary and Alternative Medicine . 
Volume Article ID

101624, 10 pages.

Lako J; Trenerry VC; Wahlqvist M; Wattanapenpaiboon $\mathbf{N}$; Sotheeswaran $S$ and Premier R (2007):

Phytochemical flavonols, carotenoids and the antioxidant properties of a wide selection of Fijian fruit, vegetables and other readily available foods. Food Chemistry, 101: 1727-1741.

Levine LH; Bisbee PA; Richards J T; Birmele M N; Prior RL; Perchonok M; Dixon M; Yorio NC; Stutte GW and Wheeler RM (2008):

Quality characteristics of the radish grown under reduced atmospheric pressure. Advances in Space Research. 41(5): 754-762.

Li G; Zhu Y; Zhang Y; lang J; Chen Yand Ling W (2013):

Estimated daily flavonoid and stilbene intake from fruits, vegetables and nuts and associations with lipid profiles in Chinese adults. Journal of the Academy of Nutrition and Dietetics. 113(6): 786-792.

Lin LZ; Sun J; Chen $P$ and Harnly JA (2011): LC-PDA-ESI/MS identification of new anthocyanins in purple Bordeaux radish Raphanus sativus L. variety). J Agric Food Chem., 59:6616-6627.

Lugasi A; Blazovics A; Hagymasi K; Kocsis I and Kery $A$ (2005):

Antioxidant effect of squeezed juice from black radish (Raphanus sativus L. var niger) in alimentary hyperlipidaemia in rats. Phytother Res., 19:587591.

Mariee AD; Abd-Allah GM and EL-Beshbishy $H$ A (2012):

Protective effect of Dietary flavonoid quercetin against lipemicoxidative hepatic injury in Hypercholesterolemic rats. 
Pharm.Bioi., 50(8): 10191025.

Mirmiran P; Noori N; Zavareh MB and Azizi F (2009):

Fruit and vegetable consumption and risk factors for cardiovascular disease. Metabolism 58:460-8.

Mithen R; Bennett $\mathbf{R}$ and Marquez J (2010):

Glucosinolate biochemical diversity and innovation in the Brassicales.

Phytochemistry . 71:20742086. Nutrient Data Laboratory Home Page, http://www.ars.usda.gov/b a/bhnrc/ndl

\section{Parinita K (2012):}

Study of serum lipid profile in individuals residing in and around Nalgonda. Int. J. pharm. Bio. Sci., 2:110-116.

Pengzhan Y; Ning L; Xiguang L; Gefei Z; Quanbin Z; Pengcheng L(2003):
Antihyperlipidemic activity of high sulfate content derivative of polysaccharide extracted from Ulva pertusa (Chlorophyta).Pharmacol Res., 48 (6):543

Prince CT; Becker D J; Costacou T; Miller RG.and Orchard TJ (2007):

Changes in glycaemic control and risk of coronary artery disease in type 1 diabetes mellitus: Findings from the Pittsburgh Epidemiology of Diabetes Complications Study (EDC). Diabetologia. 50: 22802288.

Pushparaj P; Tan C and Tan B (2000):

Effects of Averrhoe bllimll leaf extract on blood glucose and lipids in streptozotocin diabetic rats. J. Ethnopharmacol., 72: 69-76.

Rahman M; Rahman F;

Fatima N; Akter F; Rahman A; Haque M; 
Islam J; Nahar T; Uddin $B$; Ahmed $M$ and Hossain S (2013):

Spectra of alternative the rapies of hypercholesterolemia by dietary bioactives: emphasis on nutrigenomics of polyphenols. Inn. J. Food Sci., 1(1): 1-7

Reeves PG; Nielsen FH and Fahey GCJ (1993):

AIN-93 purified diets for laboratory rodents: final report of the American Institute of Nutrition adhoc writing committee on the reformulation of the AIN- 76 A rodent diet. J. Nutr., 123: 1939-1951.

Sadasivam S and Manickam A (1997):

Biochemical Methods. $2^{\text {nd }}$ Edn., New Age International Ltd. Publishers, New Delhi. PP 10-11.

Sadeek EA (2011):

Protective effect of fresh juice from red beetroot (Beta vulgaris L.) and radish (Raphanus sativus
L.) against carbon tetrachloride - induced hepatotoxicity in rats models. African J. Biol. Sci., 7(1): 69-84.

Shahdat H; Hashimoto M; Shimada T; Shido $O$ and Synaptic A (2004):

plasma membrane-bound acetylcholinesterase activity is not affected by docosahexaenoic acidinduced decrease in membrane order. Life sci., 74: 3009-24.

Shin T; Ahn M; Kim GO and Park SU (2015):

Biological activity of various radish species. Pharm. Exp. .Med., .15:105-111.

Shukla S; Chatterji S; Mehta S; Rai PK; Singh R K; Yadav D K and Watal G (2011):

Antidiabetic effect of Raphanus sativus root juice. Pharm. Bio., 49(1):32-37.

Standl E; Müller $M$ and Schnell O (2009): 
The impact of glucoselowering therapy on cardiovascular outcomes. Best Pract Res Clin. Endocrinol Metab., 23: 401-411.

\section{Suh SJ; Moon SK and Kim} CH (2006):

Raphanus sativus and its isothiocyanates inhibit vascular smooth muscle cells proliferation and induce $\mathrm{G}(1)$ cell cycle arrest. Int. Immunopharmacol., 6:854-861.

\section{Tamura S; Tsuji K; Yongzhen}

P; Ohnishi-Kameyama $M$ and Murakami N (2010):

Six new acylated anthocyanins from red radish (Raphanus sativus). Chem Pharm Bull (Tokyo) 58:1259-1262.

Taniguchi H; KobayashiHattori K; Tenmyo C; Kamei T; Uda Y; SugitaKonishi Y; Oishi Y and Takita T(2006):

Effect of Japanese Radish (Raphanus sativus) Sprout
(Kaiware-daikon) on Carbohydrate and Lipid Metabolisms in Normal and Streptozotocininduced Diabetic Rats. Phytother. Res., 20: 274 278.

Tomkin G H (2010):

Atherosclerosis, diabetes and lipoproteins. Expert Rev Cardiovasc Ther 8 , $1015-1029$.

Tourlouki E; Matalas A L and Panagiotakos D B (2009): Dietary habits and cardiovascular disease risk in middle-aged and elderly populations: a review of evidence. Clin. Interv. Aging. 4:319-30.

Tripathi KD (2003):

Essentials of medical pharmacology. $5^{\text {th }}$ ed. New Delhi, India: Published by Jaypee Brothers; 245-8.

Vinayagam $R$ and $\mathrm{Xu} \quad \mathrm{B}$ (2015):

Antidiabetic properties of dietary flavonoids: acellular mechanism 
review. Nutr. And Metab., 12(60): 1-20.

Yang B; Wang JS; Zhao MM (2006):

Identification

of polysaccharides from pericarp tissues of litchi (Litchi chinensis Sonn.) fruit in relation to their antioxidant activities. Carbohydr. Res., 341: 634- 638 .

\section{Yoshida M; Kimura H; Kyuki} $K$ and Ito $M$ (2005):

Effect of combined vitamin $\mathrm{E}$ and insulin administration on renal damage in diabetic rats fed a high cholesterol diet. Biol. Pharm .Bull., 28:2080-6.

\section{Zhao H L; Harding SV;} Marinangeli CP; Kim YS and Jones PJ (2008):

Hypocholesterolemic and anti-obesity effects of saponins from Platycodon grandiflorum in hamsters fed atherogenic diets. J. Food Sci., 73:195-200.. 
Antidiabetic and Antiatherosclerotic activity of dried red radish roots (Raphanus sativus $L$ ) on hypercholesterolemic diabetic rats

Abeer A. Khedr-Naglaa A. El Sheikh

Table (1): Total phenolic, total flavonoids, anthocyanin , antioxidant activity and proximate chemical composition of dried red radish roots.

\begin{tabular}{|l|c|}
\hline Parameters & Dried red radish root \\
\hline $\begin{array}{l}\text { Total phenolic compounds (mg gallic } \\
\text { acid/100 g) }\end{array}$ & $11.68 \pm 3.95$ \\
\hline Total Flavonoids (mg catechin/100 g) & $18.52 \pm 0.47$ \\
\hline $\begin{array}{l}\text { Anthocyanin (mg cyanidin-3-glucoside/100 } \\
\text { g) }\end{array}$ & $29.69 \pm 1.63$ \\
\hline Antioxidant activity (\%) & $82.15 \pm 1.67$ \\
Caloric values (Kcal) & $226.5 \pm 9.94$ \\
\hline Moisture (g/100 g) & $16.49 \pm 1.61$ \\
\hline Total fat (g/100 g) & $0.62 \pm 0.16$ \\
\hline Crude protein $(\mathrm{g} / 100 \mathrm{~g})$ & $6.67 \pm 1.08$ \\
\hline Carbohydrate $(\mathrm{g} / 100 \mathrm{~g})$ & $48.56 \pm 2.47$ \\
\hline Fiber $(\mathrm{g} / 100 \mathrm{~g})$ & $21.06 \pm 3.17$ \\
\hline Total ash $(\mathrm{g} / 100 \mathrm{~g})$ & $6.60 \pm 2.06$ \\
\hline & \\
\hline
\end{tabular}

Each value in the table is the mean \pm standard deviation of three replicates. 
Antidiabetic and Antiatherosclerotic activity of dried red radish roots (Raphanus sativus $L$ ) on hypercholesterolemic diabetic rats

Abeer A. Khedr-Naglaa A. El Sheikh

Table (2): Effect of dried red radish roots on glucose in blood and urine and insulin in normal and hypercholesterolemic diabetic rats

\begin{tabular}{|c|c|c|c|c|c|}
\hline \multirow[t]{2}{*}{ Parameters } & \multirow[t]{2}{*}{ Normal rats } & \multicolumn{4}{|c|}{ Hypercholesterolemic diabetic rats } \\
\hline & & $\begin{array}{l}\text { 0\% red } \\
\text { radish roots }\end{array}$ & $\begin{array}{l}2.5 \% \text { red } \\
\text { radish roots }\end{array}$ & $\begin{array}{c}5 \% \text { red } \\
\text { radish } \\
\text { roots }\end{array}$ & $\begin{array}{l}7.5 \% \text { red } \\
\text { radish } \\
\text { roots }\end{array}$ \\
\hline \multicolumn{6}{|c|}{ Glucose in blood mg/dl } \\
\hline First day & $\begin{array}{c}99.39^{\mathrm{Ab}} \pm \\
0.69\end{array}$ & $\begin{array}{c}310.73^{\mathrm{Ba} a} \pm \\
1.18\end{array}$ & $\begin{array}{c}310.18^{\mathrm{Aa}} \pm \\
1.49\end{array}$ & $\begin{array}{c}310.52^{\mathrm{Aa}} \pm \\
1.71\end{array}$ & $\begin{array}{c}309.90^{\mathrm{Aa}} \pm \\
1.06\end{array}$ \\
\hline Final day & $\begin{array}{c}98.32^{\mathrm{Ae}} \pm \\
1.37\end{array}$ & $\begin{array}{c}320.17^{\mathrm{Aa}} \pm \\
1.11\end{array}$ & $\begin{array}{c}235.15^{\mathrm{Bb}} \pm \\
0.86\end{array}$ & $\begin{array}{c}194.73^{\mathrm{Bc}} \pm \\
2.20\end{array}$ & $\begin{array}{c}154.47^{\mathrm{Bd}} \pm \\
1.08\end{array}$ \\
\hline $\begin{array}{c}\text { \% lowering of } \\
\text { blood glucose level }\end{array}$ & 1.08 & - & 24.2 & 37.29 & 50.15 \\
\hline \multicolumn{6}{|c|}{ Glucose in urine $\mathrm{mmol} / \mathrm{L}$} \\
\hline First day & 0.0 & $\begin{array}{c}57.95^{\mathrm{Ba}} \pm \\
1.46\end{array}$ & $\begin{array}{c}57.21^{\mathrm{Aa}} \pm \\
0.93\end{array}$ & $\begin{array}{c}57.09^{\mathrm{Aa}} \pm \\
1.21\end{array}$ & $\begin{array}{c}58.43^{\mathrm{Aa}} \pm \\
0.95\end{array}$ \\
\hline Final day & 0.0 & $\begin{array}{c}68.32^{\mathrm{Aa}} \pm \\
1.31\end{array}$ & $\begin{array}{c}40.44^{\mathrm{Bb}} \pm \\
0.91\end{array}$ & $\begin{array}{c}28.28^{\mathrm{Bc}} \pm \\
1.44\end{array}$ & $\begin{array}{c}17.56^{\mathrm{Bd}} \pm \\
0.59\end{array}$ \\
\hline $\begin{array}{c}\text { \% lowering of } \\
\text { urine glucose level }\end{array}$ & 0.0 & - & 29.31 & 50.46 & 69.95 \\
\hline \multicolumn{6}{|c|}{ Insulin in serum $(\mathbf{n g} / \mathbf{m g})$} \\
\hline First day & $\begin{array}{c}2.51^{\mathrm{Aa}} \pm \\
0.10\end{array}$ & $\begin{array}{c}0.49^{\mathrm{Ab}} \pm \\
0.35\end{array}$ & $\begin{array}{c}0.51^{\mathrm{Bb}} \pm \\
0.03\end{array}$ & $\begin{array}{c}0.45^{\mathrm{Bb}} \pm \\
0.04\end{array}$ & $\begin{array}{c}0.52^{\mathrm{Bb}} \pm \\
0.05\end{array}$ \\
\hline Final day & $\begin{array}{c}2.54^{\mathrm{Aa}} \pm \\
0.13\end{array}$ & $\begin{array}{c}0.49^{\mathrm{Ae}} \pm \\
0.04\end{array}$ & $\begin{array}{c}0.75^{\mathrm{Ad}} \pm \\
0.01\end{array}$ & $\begin{array}{c}0.98^{\mathrm{Ac}} \pm \\
0.01\end{array}$ & $\begin{array}{c}1.24^{\mathrm{Ab}} \pm \\
0.09\end{array}$ \\
\hline $\begin{array}{c}\text { \% change of } \\
\text { Insulin in serum }\end{array}$ & 0.0 & 0.0 & 47.06 & 117.78 & 138.46 \\
\hline $\begin{array}{l}\text { Insulin sensitivity } \\
\text { index (HOMA-IR) }\end{array}$ & $\begin{array}{c}25.75^{\mathrm{a}} \pm \\
1.47\end{array}$ & $\begin{array}{c}16.20^{\mathrm{d}} \pm \\
1.17\end{array}$ & $\begin{array}{c}18.14^{\mathrm{c}} \pm \\
0.35\end{array}$ & $\begin{array}{c}19.68^{\mathrm{b}} \pm \\
0.35\end{array}$ & $\begin{array}{c}19.66^{\mathrm{b}} \pm \\
1.31\end{array}$ \\
\hline
\end{tabular}

Data are expressed as mean \pm SD. Values within a row having different superscripts are significantly different $(\mathrm{p} \leq 0.05)$; where the small letters indicate significant among dietary treatment groups as indicated by one-way ANOVA followed by Duncan's 
Antidiabetic and Antiatherosclerotic activity of dried red radish roots (Raphanus sativus $L$ ) on hypercholesterolemic diabetic rats

Abeer A. Khedr-Naglaa A. El Sheikh

multiple range test $(\mathrm{a}>\mathrm{b}>\mathrm{c}>\mathrm{d}>\mathrm{e})$, while capital letters referred to statistical differences among experimental periods, HOMA-IR:

Table (3): Effect of dried red radish roots on serum lipid profile in normal and hypercholesterolemic diabetic rats

\begin{tabular}{|c|c|c|c|c|c|}
\hline \multirow[t]{2}{*}{ Parameters } & \multirow{2}{*}{$\begin{array}{c}\text { Normal } \\
\text { rats }\end{array}$} & \multicolumn{4}{|c|}{ Hypercholesterolemic diabetic rats } \\
\hline & & $\begin{array}{c}\text { 0\% red } \\
\text { radish } \\
\text { roots }\end{array}$ & $\begin{array}{c}2.5 \% \text { red } \\
\text { radish } \\
\text { roots }\end{array}$ & $\begin{array}{c}5 \% \text { red } \\
\text { radish } \\
\text { roots }\end{array}$ & $\begin{array}{c}7.5 \% \text { red } \\
\text { radish } \\
\text { roots }\end{array}$ \\
\hline T.C(mg/dl) & $\begin{array}{c}98.08^{\mathrm{d}} \pm \\
1.12\end{array}$ & $\begin{array}{c}208.70^{\mathrm{a}} \pm \\
2.97\end{array}$ & $\begin{array}{c}207.39^{\mathrm{a}} \pm \\
4.1\end{array}$ & $\begin{array}{c}177.10^{b} \\
\pm 2.19\end{array}$ & $\begin{array}{c}158.11^{\mathrm{c}} \pm \\
5.07\end{array}$ \\
\hline $\begin{array}{c}\text { T.G } \\
(\mathrm{mg} / \mathrm{dl})\end{array}$ & $\begin{array}{c}85.41^{\mathrm{e}} \pm \\
1.04\end{array}$ & $\begin{array}{c}166.48^{\mathrm{a}} \pm \\
2.50\end{array}$ & $\begin{array}{c}160.29^{b} \pm \\
3.26\end{array}$ & $\begin{array}{r}132.15^{\mathrm{c}} \\
\pm 2.76\end{array}$ & $\begin{array}{c}114.22^{\mathrm{d}} \pm \\
2.08\end{array}$ \\
\hline $\begin{array}{l}\text { HDL.c } \\
\text { (mg/dl) }\end{array}$ & $\begin{array}{c}57.24^{\mathrm{a}} \pm \\
1.05\end{array}$ & $\begin{array}{c}24.80^{\mathrm{d}} \pm \\
2.26\end{array}$ & $\begin{array}{c}26.16^{\mathrm{d}} \pm \\
1.83\end{array}$ & $\begin{array}{c}38.17^{\mathrm{c}} \pm \\
2.09\end{array}$ & $\begin{array}{c}46.67^{b} \pm \\
2.22\end{array}$ \\
\hline $\begin{array}{c}\text { LDL.c } \\
(\mathrm{mg} / \mathrm{dl})\end{array}$ & $\begin{array}{c}23.76^{\mathrm{d}} \pm \\
1.91\end{array}$ & $\begin{array}{c}150.61^{\mathrm{a}} \pm \\
4.60\end{array}$ & $\begin{array}{c}149.17^{\mathrm{a}} \pm \\
3.57\end{array}$ & $\begin{array}{c}112.50^{\mathrm{b}} \pm \\
3.69\end{array}$ & $\begin{array}{c}88.60^{c} \pm \\
4.22\end{array}$ \\
\hline $\begin{array}{l}\text { VLDl.c } \\
\text { (mg/dl) }\end{array}$ & $\begin{array}{c}17.08^{\mathrm{e}} \pm \\
0.21\end{array}$ & $\begin{array}{c}33.29^{\mathrm{a}} \pm \\
0.50\end{array}$ & $\begin{array}{c}32.06^{b} \pm \\
0.65\end{array}$ & $\begin{array}{c}26.43^{c} \pm \\
0.55\end{array}$ & $\begin{array}{c}22.84^{\mathrm{d}} \pm \\
0.42\end{array}$ \\
\hline
\end{tabular}

Data are expressed as mean \pm SD. Values within a row having different superscripts are significantly different $(\mathrm{p} \leq 0.05)$; where the small letters indicate significant among dietary treatment groups as indicated by one-way ANOVA followed by Duncan's multiple range test $(a>b>c>d>e)$ 
Table (4): Effect of dried red radish roots on atherogenic indices and LDL/HDL Ratio (HTR \%) in normal and hypercholesterolemic diabetic rats .

\begin{tabular}{|c|c|c|c|c|c|}
\hline \multirow[t]{2}{*}{ Parameters } & \multirow{2}{*}{$\begin{array}{c}\text { Normal } \\
\text { rats }\end{array}$} & \multicolumn{4}{|c|}{ Hypercholesterolemic diabetic rats } \\
\hline & & $\begin{array}{c}\text { 0\% red } \\
\text { radish } \\
\text { roots }\end{array}$ & $\begin{array}{c}2.5 \% \text { red } \\
\text { radish } \\
\text { roots }\end{array}$ & $\begin{array}{c}5 \% \text { red } \\
\text { radish } \\
\text { roots }\end{array}$ & $\begin{array}{c}7.5 \% \\
\text { red } \\
\text { radish } \\
\text { roots }\end{array}$ \\
\hline AI (mg/dl) & $\begin{array}{c}0.17^{\mathrm{e}} \pm \\
0.01\end{array}$ & $\begin{array}{c}0.83^{\mathrm{a}} \pm \\
0.40\end{array}$ & $\begin{array}{c}0.79^{\mathrm{b}} \pm \\
0.03\end{array}$ & $\begin{array}{c}0.54^{\mathrm{c}} \pm \\
0.03\end{array}$ & $\begin{array}{c}0.39^{\mathrm{d}} \pm \\
0.02\end{array}$ \\
\hline CRR & $\begin{array}{c}1.71^{\mathrm{d}} \pm \\
0.04\end{array}$ & $\begin{array}{c}8.42^{\mathrm{a}} \pm \\
0.87\end{array}$ & $\begin{array}{c}7.93^{\mathrm{a}} \pm \\
0.52\end{array}$ & $\begin{array}{c}4.64^{b} \pm \\
0.29\end{array}$ & $\begin{array}{c}3.39^{c} \pm \\
0.13\end{array}$ \\
\hline CRI (mg/dl) & $\begin{array}{c}0.42^{\mathrm{d}} \pm \\
0.04\end{array}$ & $\begin{array}{c}6.07^{\mathrm{a}} \pm \\
0.74\end{array}$ & $\begin{array}{c}5.70^{\mathrm{a}} \pm \\
0.44\end{array}$ & $\begin{array}{c}2.95^{b} \pm \\
0.44\end{array}$ & $\begin{array}{c}1.90^{\mathrm{c}} \pm \\
0.12\end{array}$ \\
\hline AF (mg/dl) & $\begin{array}{c}40.84^{\mathrm{d}_{ \pm}} \\
1.89\end{array}$ & $\begin{array}{c}183.9^{\mathrm{a}} \pm \\
4.69\end{array}$ & $\begin{array}{c}181.23^{\mathrm{a}} \pm \\
3.64\end{array}$ & $\begin{array}{l}138.93^{\mathrm{b}} \\
\pm 3.72\end{array}$ & $\begin{array}{r}111.44^{\mathrm{c}} \\
\pm 4.37\end{array}$ \\
\hline $\mathrm{AC}(\mathrm{mg} / \mathrm{dl})$ & $\begin{array}{c}0.72^{\mathrm{d}} \pm \\
0.04\end{array}$ & $\begin{array}{c}7.48^{\mathrm{a}} \pm \\
0.87\end{array}$ & $\begin{array}{c}6.96^{\mathrm{a}} \pm \\
0.52\end{array}$ & $\begin{array}{c}3.65^{b} \pm \\
0.29\end{array}$ & $\begin{array}{c}2.39^{c} \pm \\
0.13\end{array}$ \\
\hline HTR\% & $\begin{array}{c}0.58^{\mathrm{a}} \pm \\
0.06\end{array}$ & $\begin{array}{c}0.12^{\mathrm{d}} \pm \\
0.02\end{array}$ & $\begin{array}{c}0.13^{\mathrm{d}} \pm \\
0.01\end{array}$ & $\begin{array}{c}0.22^{\mathrm{c}} \pm \\
0.01\end{array}$ & $\begin{array}{c}0.30^{\mathrm{b}} \pm \\
0.01\end{array}$ \\
\hline
\end{tabular}

Data are expressed as mean \pm SD. Values within a row having different superscripts are significantly different $(\mathrm{p} \leq 0.05)$; where the small letters indicate significant among dietary treatment groups as indicated by one-way ANOVA followed by Duncan's multiple range test $(\mathrm{a}>\mathrm{b}>\mathrm{c}>\mathrm{d}>\mathrm{e})$. Atherogenic Index $(\mathrm{AI})=\log$ TG/HDLc, Cardiac risk ratio $(\mathrm{CRR})=\mathrm{TC} / \mathrm{HDLc}$, Castelli's Risk Index $(\mathrm{CRI})=$ LDLc/HDLc Atherogenic Coefficient $(\mathrm{AC})=(\mathrm{TC}-\mathrm{HDLc}) / \mathrm{HDLc}$, Atherogenic fraction $(\mathrm{AF})$ was calculated as the difference between TC and HDL-C, HTR = HDL/TC Ratio. 
Table (5): Effect of dried red radish roots on hepatic lipid parameters in normal and hypercholesterolemic diabetic rats

\begin{tabular}{|c|c|c|c|c|c|}
\hline \multirow[t]{2}{*}{ Parameters } & \multirow{2}{*}{$\begin{array}{l}\text { Normal } \\
\text { rats }\end{array}$} & \multicolumn{4}{|c|}{ Hypercholesterolemic diabetic rats } \\
\hline & & $\begin{array}{c}\text { 0\% red } \\
\text { radish } \\
\text { roots }\end{array}$ & $\begin{array}{c}2.5 \% \text { red } \\
\text { radish } \\
\text { roots }\end{array}$ & $\begin{array}{c}5 \% \text { red } \\
\text { radish } \\
\text { roots }\end{array}$ & $\begin{array}{c}7.5 \% \text { red } \\
\text { radish } \\
\text { roots }\end{array}$ \\
\hline $\begin{array}{c}\text { T.L } \\
\text { (Mmol/g tit) }\end{array}$ & $\begin{array}{c}1.79^{\mathrm{e}} \pm \\
0.06\end{array}$ & $\begin{array}{c}3.87^{\mathrm{a}} \pm \\
0.28\end{array}$ & $\begin{array}{c}3.09^{b} \pm \\
0.08\end{array}$ & $\begin{array}{c}2.56^{\mathrm{c}} \pm \\
0.08\end{array}$ & $\begin{array}{c}2.19^{\mathrm{d}} \pm \\
0.18\end{array}$ \\
\hline $\begin{array}{c}\text { T.G } \\
(\mathrm{Mmol} / \mathrm{g} \text { tit) }\end{array}$ & $\begin{array}{c}0.73^{\mathrm{e}} \pm \\
0.05\end{array}$ & $\begin{array}{c}1.95^{\mathrm{a}} \pm \\
0.03\end{array}$ & $\begin{array}{c}1.39^{\mathrm{b}} \pm \\
0.05\end{array}$ & $\begin{array}{c}1.11^{\mathrm{c}} \pm \\
0.04\end{array}$ & $\begin{array}{c}0.95^{\mathrm{d}} \pm \\
0.03\end{array}$ \\
\hline $\begin{array}{c}\text { T.C } \\
\text { (Mmol/g tit) }\end{array}$ & $\begin{array}{c}91.38^{\mathrm{d}} \pm \\
1.02\end{array}$ & $\begin{array}{c}224.27^{\mathrm{a}} \\
\pm 3.65\end{array}$ & $\begin{array}{c}221.96^{\mathrm{a}} \pm \\
2.59\end{array}$ & $\begin{array}{c}154.91^{\mathrm{b}} \pm \\
3.88\end{array}$ & $\begin{array}{c}138.87^{\mathrm{c}} \pm \\
3.05\end{array}$ \\
\hline
\end{tabular}

Data are expressed as mean $\square \mathrm{SD}$. Values within a row having different superscripts are significantly different $(\mathrm{p} \leq 0.05)$; where the small letters indicate significant among dietary treatment groups as indicated by one-way ANOVA followed by Duncan's multiple range test $(a>b>c>d>e)$. 
Antidiabetic and Antiatherosclerotic activity of dried red radish roots (Raphanus sativus $L$ ) on hypercholesterolemic diabetic rats

Abeer A. Khedr-Naglaa A. El Sheikh

Fig.(1): Histopathological changes of aorta tissue in normal and hypercholesterolemic diabetic rats.

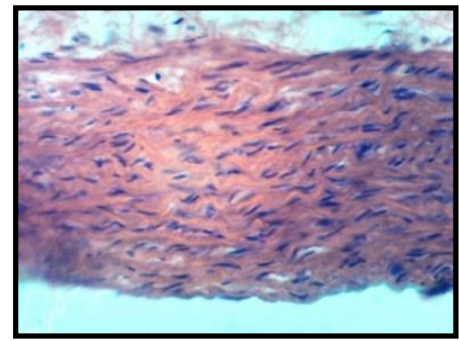

A
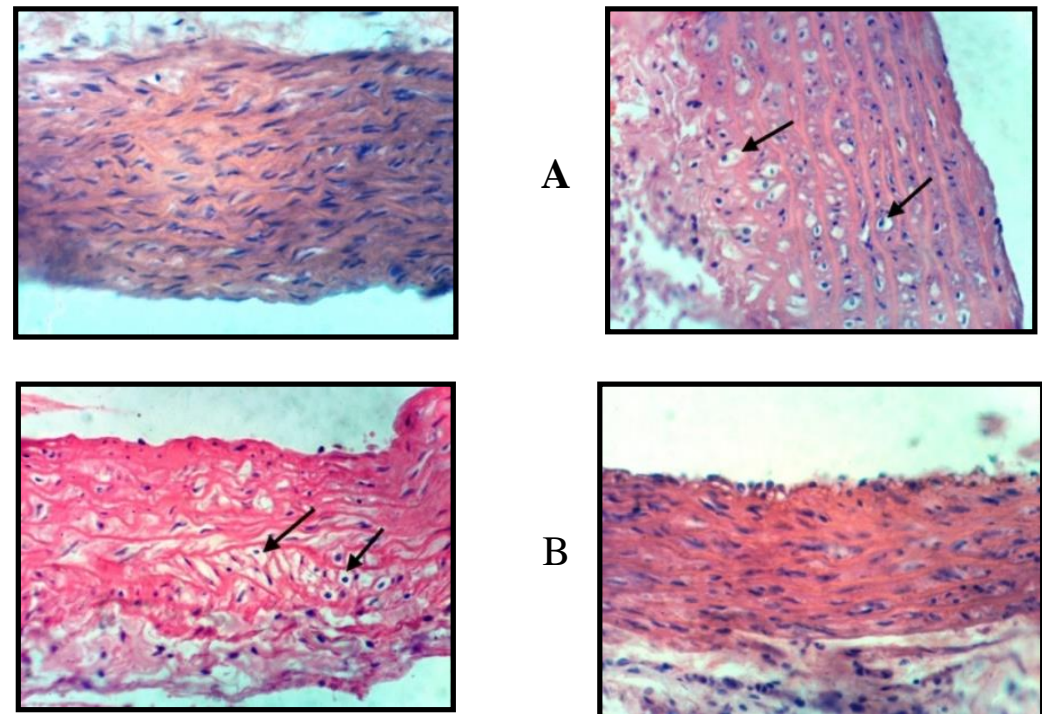

B
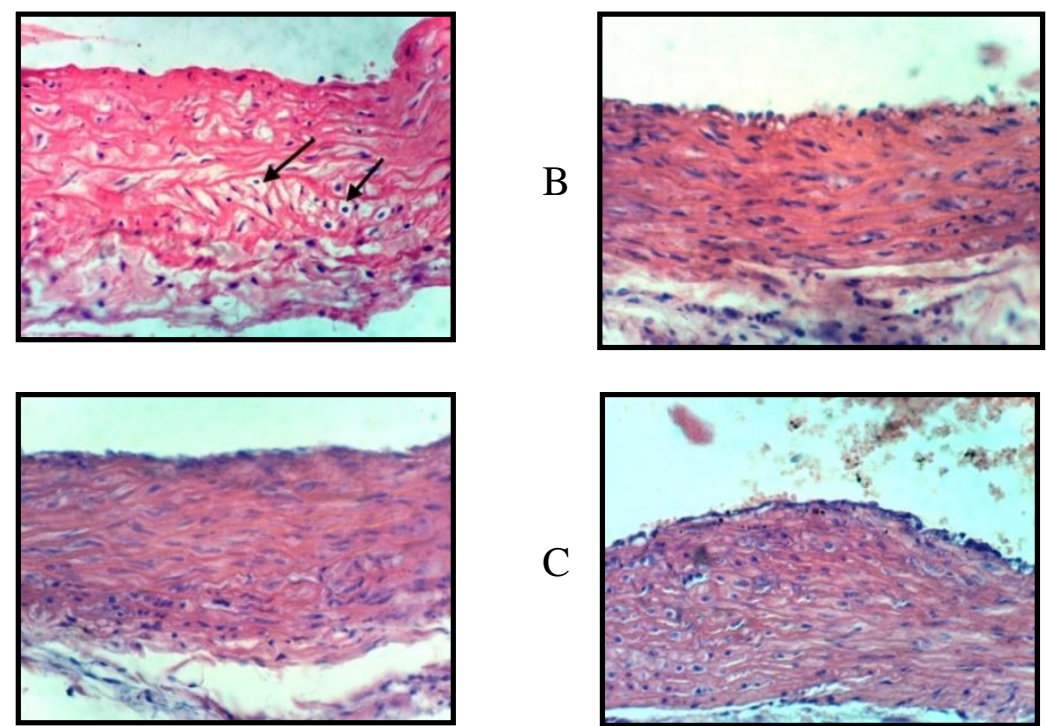

$\mathrm{C}$
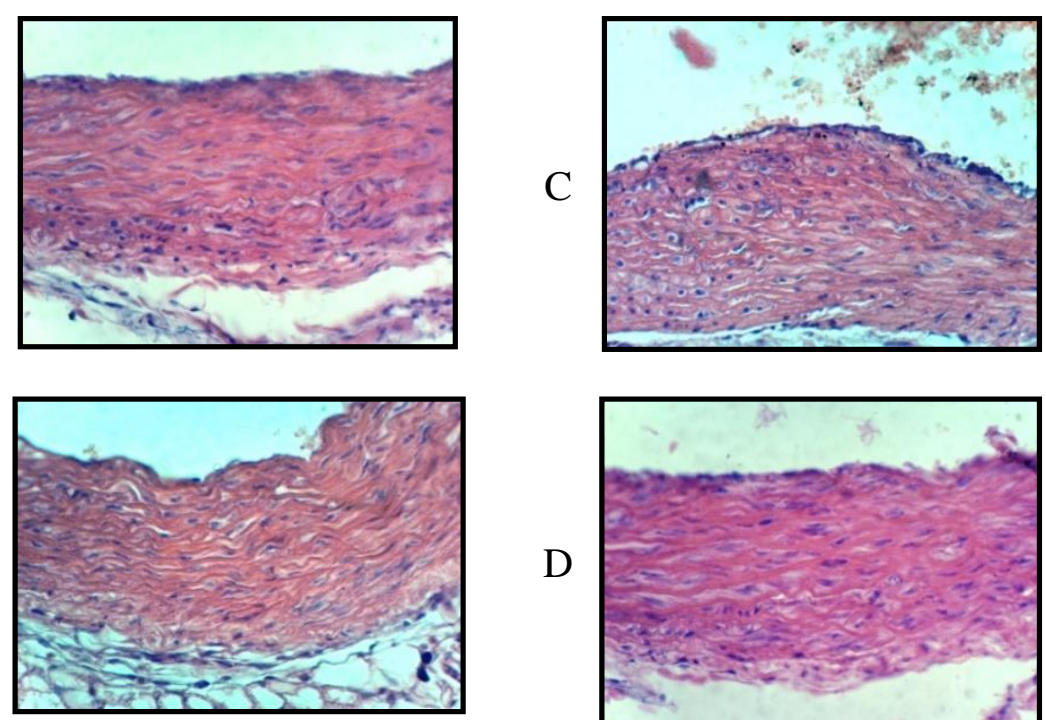

$\mathrm{D}$

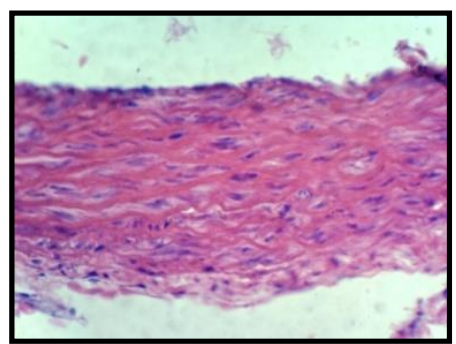




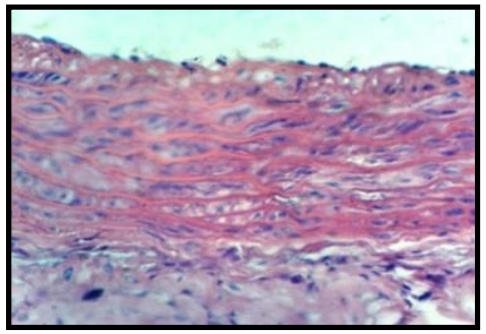

E

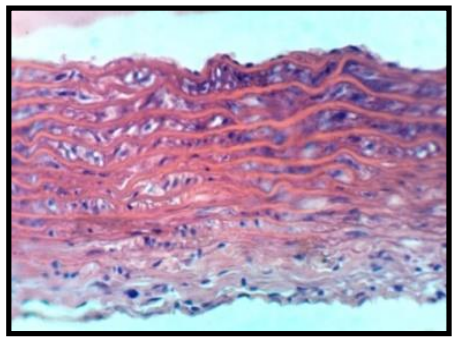

A: normal control, B: Hypercholesterolemic diabetic rats untreated $(0 \%$ red radish roots), $\mathrm{C}$ : Hypercholesterolemic diabetic rats treated with $2.5 \%$ red radish roots, D: Hypercholesterolemic diabetic rats treated with $5 \%$ red radish roots, E: Hypercholesterolemic diabetic rats treated with $7.5 \%$ red radish roots. 


\section{النشاط المضاد للسكرى وتصلب الثرايين لجذور الفجل الأحمر الجافة في الجرذان المصابة بالسكرى

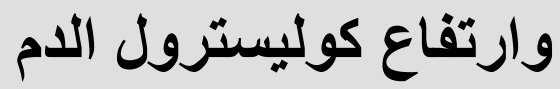 \\ عبير أحمد خضر و نجلاء على مجد الثيخ \\ قسم التغذية و علوم الأطعمة بكلية الاقتصاد المنزلي جامعة المنوفية ، شبين الكوم، مصر الملخص العربى}

هذه الدراسة /جربت لتقبيم التاثبر الخافض لسكر الدم و الدضاد لتصلب الثرابين

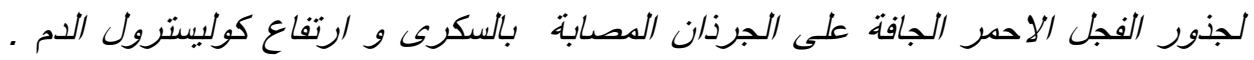

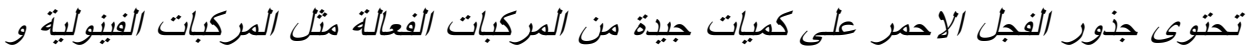

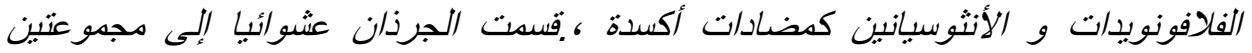

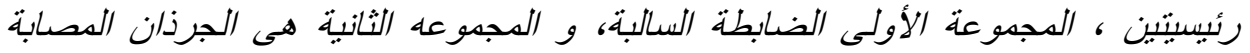

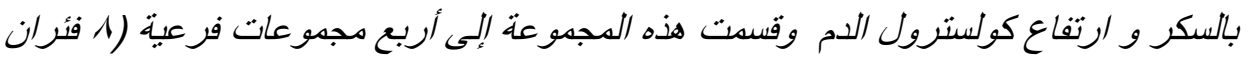

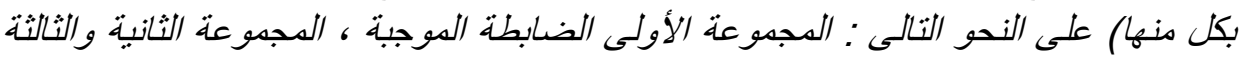

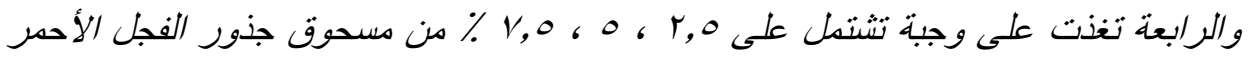

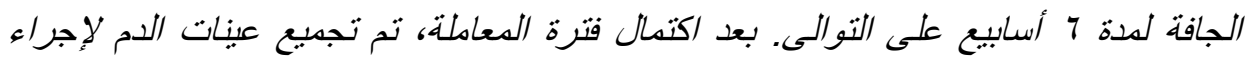

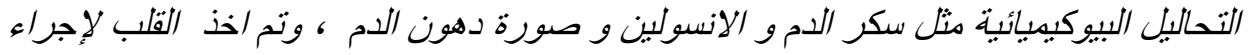

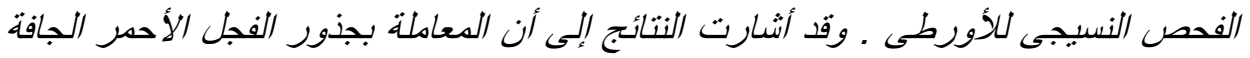

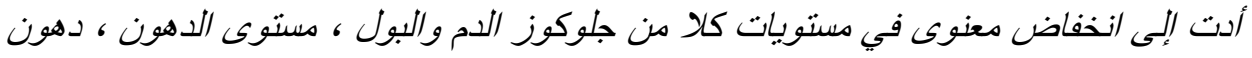
الكبد ومؤشرات التجلط مقارنة بالدجموعة الضابطة الدوجبة دع تحسن في دستوى الإنسولين

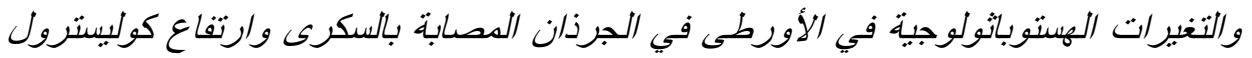

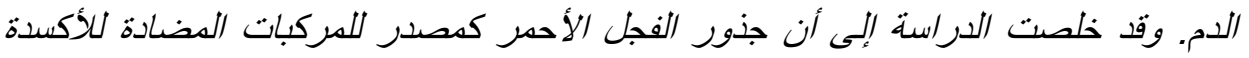
لديها تأثبر مخفض للسكروتحسين ميتابوليزم الدهون مع الوقابة من أمراض الأوعية الدموية. الكلمات الكشافة : جذور الفجل الأحمر- مؤشرات التجلط - النشاط المضاد للسكرى الجرذان المصابة بالسكرى وارتفاع كوليبنرول الدم. 